\title{
Insight Into the Structure Elucidation of Flavonoids Through UV-Visible Spectral Analysis of Quercetin Derivatives Using Shift Reagents
}

\author{
Gan B. Bajracharya ${ }^{1 *}$, Mohan Paudel ${ }^{2}$ and Rajendra K.C. ${ }^{2}$ \\ ${ }^{I}$ Faculty of Science, Nepal Academy of Science and Technology (NAST), Khumaltar, Lalitpur, Nepal \\ ${ }^{2}$ Department of Chemistry, Tri-Chandra Multiple Campus, Tribhuvan University, Kathmandu, Nepal \\ Email: ganbajracharya@yahoo.com
}

\begin{abstract}
Quercetin derivatives (2-15) were synthesized. The structure of the compounds was confirmed by the study of UV-Vis spectra using various shift reagents such as $\mathrm{NaOAc}, \mathrm{NaOAc}+\mathrm{H}_{3} \mathrm{BO}_{3}, \mathrm{AlCl}_{3}, \mathrm{AlCl}_{3}+\mathrm{HCl}$ and $\mathrm{NaOH}$. This study could put forth some generalizations in the established rules used in the identification of flavonoids by UV-Vis spectroscopy.
\end{abstract}

Keywords: flavonols, synthesis, UV-Vis spectroscopy

\section{Introduction}

Flavonoids are benzo- $\gamma$-pyrones comprising two benzene rings (rings A and B), which are linked by one pyran ring (ring C) (Figure 1) ) $^{1,2}$ Various classes of flavonoids are due to differences in the benzene ring attachment position, level of oxidation and pattern of substitution in the $\mathrm{C}$ ring, while individual compound within a class differs in the pattern of substitutions in the A and B rings. Flavones, flavonols, flavanones, catechins, isoflavones, and anthocyanidins are the major classes of flavonoids. Because of myriad of possible structural modifications, more than 6,467 different compounds from this family are known and this number continues to increase ${ }^{3}$.

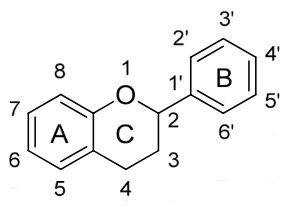

a

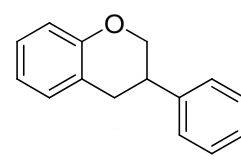

b

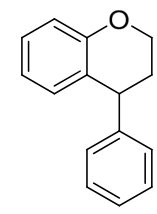

C

Figure 1: Main classes of flavonoids: (a) flavonoids, (b) isoflavonoids, and (c) neoflavonoids.

Absorptions due to the benzene rings $\mathrm{A}$ and $\mathrm{B}$, and their possible conjugations to ring $\mathrm{C}$ give rise to the UV-Vis spectra of flavonoids. All flavonoids show an absorption maximum at around 240-290 nm (band II, due to absorption of benzoyl system), which varies by the conjugation of ring $\mathrm{A}$ and its substitution pattern ${ }^{4}$. Some flavonoids in which rings B and C are conjugated (via a double bond between

\footnotetext{
* Corresponding author
} 


\section{J. Nepal Chem. Soc., Vol.37, 2017}

carbons C2 and C3 in ring C), have another absorbance maximum at around 300-550 nm (band I, due to absorption of cinnamoyl system). This absorption maximum is at around 460-550 nm for anthocyanins, and 305-385 $\mathrm{nm}$ for flavones and flavonols.

The use of UV-Vis shift reagents such as $\mathrm{NaOAc}, \mathrm{NaOAc}+\mathrm{H}_{3} \mathrm{BO}_{3}, \mathrm{AlCl}_{3}, \mathrm{AlCl}_{3}+\mathrm{HCl}$ and $\mathrm{NaOH}$ has proven to be very useful in determining the substitution patterns of flavonoids, since these shift reagents cause characteristic shifts in the bands appeared in the methanolic solution of the pure sample. Generally, methanolic solution of flavones produces band I maxima at 305-350 nm, while flavonols absorb between 350-385 nm. The use of NaOAc, a weaker base, ionizes only the more acidic hydroxyl groups (3, 7 and/or 4'-hydroxyl groups) in flavones and flavonols. Because ionization of the 7-hydroxyl group affects band II producing a bathochromic shift of 5-20 nm, and therefore NaOAc is particularly employed for the specific detection of 7-OH group ${ }^{5,6}$. In the presence of $\mathrm{NaOAc}$, boric acid chelates with ortho-dihydroxyl groups at all locations on the flavonoid nucleus that produces $12-30 \mathrm{~nm}$ bathochromic shift of band $\mathrm{I}$.

Flavones and flavonols containing hydroxyl groups at $\mathrm{C} 3$ or $\mathrm{C} 5$ or ortho-dihydroxyl groups form complexes with $\mathrm{AlCl}_{3}$. The complexes formed between $\mathrm{AlCl}_{3}$ and ortho-dihydroxyl groups decompose in the presence of acid, whereas, the $\mathrm{AlCl}_{3}$ complex between the $\mathrm{C} 4$ keto function and either 3-OH or 5-OH group is stable in the presence of $\mathrm{acid}^{5}$. A bathochromic shift of $60 \mathrm{~nm}$ in band I is indicative for the formation of complex between $\mathrm{AlCl}_{3}, \mathrm{C} 4$ keto function and 3-OH group in flavonoids. On the other hand, $\mathrm{AlCl}_{3}$ complex between $\mathrm{C} 4$ keto function and 5-OH group produces a bathochromic shift of 30-55 nm. To a methanolic solution of a flavone or flavonol that already contained $\mathrm{AlCl}_{3}$, addition of $\mathrm{HCl}$ decomposes the complexation between $\mathrm{AlCl}_{3}$ and ortho-dihydroxyl groups causing a hypsochromic shift of 25-30 nm in band $\mathrm{I}$ in comparison to the former spectrum.

Since $\mathrm{NaOH}$ can ionize all the hydroxyl groups of flavonoid and may lead difficult to correlate the spectral shifts obtained, this shift reagent has been used for the detection of 3-OH and/or 4'-OH groups ${ }^{5}$. Often addition of $\mathrm{NaOH}$ produces degeneration of band I. Occurrence of a small peak or shoulder at around $330 \mathrm{~nm}$ on addition of $\mathrm{NaOH}$ indicates the presence of a free $\mathrm{OH}$ at $\mathrm{C}$. Several authors have reported characteristic UV-Vis bands shifting in the presence of various shift reagents thereby indicating the substitution patterns in flavonols ${ }^{5,7-12}$. A general shifting tendency in the bands of UV-Vis spectra of flavonols using different shift reagents is briefly summarized in Table 1. It has been stressed that these rules may not be regarded as strict rules but should be considered as useful hints for structural assignments of the flavonoids.

Table 1: UV-Vis spectral characteristics of flavones and flavonols.

\begin{tabular}{|l|l|l|l|}
\hline \multicolumn{1}{|c|}{ Reagent } & \multicolumn{1}{|c|}{$\begin{array}{c}\text { Shift of band I or II } \\
(\mathbf{n m})\end{array}$} & Substitution pattern & \multicolumn{1}{|c|}{ Remarks* } \\
\hline $\mathrm{MeOH}$ & I (-8-12) & $6-\mathrm{OH}$ & Flavonols \\
\hline & I (-9) & $6-\mathrm{OH}$ & Flavones \\
\hline & I (+13-16) & $8-\mathrm{OH}$ & Flavonols \\
\hline$+\mathrm{NaOAc}$ & II (+5-20) & $7-\mathrm{OH}$ & $\begin{array}{l}\text { Minor shift when OMe at C6 and/or } \\
\text { C8 }\end{array}$ \\
\hline
\end{tabular}


J. Nepal Chem. Soc., Vol. 37, 2017

\begin{tabular}{|c|c|c|c|}
\hline & & $3,3^{\prime}, 4^{\prime}-$ triOH & Rapid decomposition \\
\hline & & 3,4'-diOH, 3'-OMe & Rapid decomposition \\
\hline \multirow{2}{*}{$\begin{array}{l}+\mathrm{NaOAc}+ \\
\mathrm{H}_{3} \mathrm{BO}_{3}\end{array}$} & $\mathrm{I}(+12-30)$ & ortho- or 3', 4'-diOH & At ring $\mathrm{B}$ \\
\hline & $\mathrm{I}(+5-10)$ & $\begin{array}{l}\text { 6,7-diOH or } 7,8- \\
\text { diOH }\end{array}$ & At ring $\mathrm{A}$ \\
\hline \multirow[t]{4}{*}{$+\mathrm{AlCl}_{3}$} & $\mathrm{I}(+60)$ & $3-\mathrm{OH}$ & \\
\hline & $\mathrm{I}(+35-55)$ & $5-\mathrm{OH}$ & \\
\hline & $\mathrm{I}(+50-60)$ & 3,5-diOH & \\
\hline & $\mathrm{I}(+20)$ & 5,6-diOH & \\
\hline \multirow[t]{7}{*}{$+\mathrm{AlCl}_{3}+\mathrm{HCl}$} & $\mathrm{I}(+50-60)$ & $3-\mathrm{OH}$ or 3,5-diOH & \\
\hline & $\mathrm{I}(+35-55)$ & $5-\mathrm{OH}$ & \\
\hline & $\mathrm{I}(+25-30)$ & $5-\mathrm{OH}, 6-\mathrm{OH}$ & \\
\hline & $\mathrm{I}(+20)$ & 5-OH, 6-OMe & $\begin{array}{l}\text { Flavones and 3-O-substituted } \\
\text { flavonols }\end{array}$ \\
\hline & $\mathrm{I}(+55-57)$ & 5-OH, 8-OMe & \\
\hline & $\mathrm{I}(-20)$ & tri-OH at ring $\mathrm{B}$ & Relative to spectrum with $\mathrm{AlCl}_{3}$ \\
\hline & I $(-30-40)$ & ortho-diOH at ring $\mathrm{B}$ & Relative to spectrum with $\mathrm{AlCl}_{3}$ \\
\hline \multirow[t]{6}{*}{$+\mathrm{NaOH}$} & $\mathrm{I}(+40-60)$ & $4^{\prime}-\mathrm{OH}$ & Increase of intensity \\
\hline & $\mathrm{I}(+50-60)$ & $3-\mathrm{OH}$ & Decrease of intensity \\
\hline & & 3,4'-diOH & Slow degeneration \\
\hline & & $3,3^{\prime}, 4^{\prime}-$ triOH & Rapid degeneration \\
\hline & & 3,3',4',5'-tetraOH & Rapid degeneration \\
\hline & & $7-\mathrm{OH}$ & $\begin{array}{l}\text { Small extra peak or shoulder at } 330 \\
\mathrm{~nm}\end{array}$ \\
\hline
\end{tabular}

\section{Experimental Methods}

\section{Chemicals and equipments}

Solvents and chemicals were obtained from Fischer, Qualigens, Merck and Loba Chemie companies. Quercetin (1) was purchased from Sigma-Aldrich. Pre-coated thin layer chromatography (TLC) plates $\left(0.2 \mathrm{~mm}\right.$ thickness, Kieselgel $\left.60 \mathrm{~F}_{254}\right)$ were procured from Merck. Silica gel (100-200 mesh, Fisher scientific) was used for column chromatography and 971-FP Flash Purification System (Agilent Technologies) equipped with silica gel column (SuperFlash SF25-40) was used for medium pressure 


\section{J. Nepal Chem. Soc., Vol.37, 2017}

liquid chromatography (MPLC). Spectrophotometric analysis was performed with a Cary 60 UV-Visible spectrophotometer (Agilent Technologies). Melting points (M. p.) were determined using a Thiel's tube and were uncorrected.

\section{Preparation of UV-Vis shift reagents}

\section{Sodium acetate}

Fused $\mathrm{NaOAc}$ was prepared by heating $2 \mathrm{~g}$ of anhydrous $\mathrm{NaOAc}$ over a small Bunsen flame with continuous stirring using a porcelain basin. The fused salt was then powdered with a pestle.

Boric acid solution: Anhydrous $\mathrm{H}_{3} \mathrm{BO}_{3}$ was saturated with redistilled water $(50 \mathrm{ml})$ by warming over a water bath. After cooling, it was filtered and filtrate was used.

Alcoholic aluminium chloride: Anhydrous $\mathrm{AlCl}_{3}(5 \mathrm{~g})$ was cautiously treated with redistilled methanol $(100 \mathrm{ml})$, allowed to stand overnight, filtered and then filtrate was used.

Hydrochloric acid solution: Conc. $\mathrm{HCl}(10 \mathrm{ml})$ was diluted with redistilled water $(20 \mathrm{ml})$ to prepare $6 \mathrm{~N} \mathrm{HCl}$ solution.

Sodium hydroxide solution: $\mathrm{NaOH}(4 \mathrm{~g})$ was dissolved in redistilled water $(50 \mathrm{ml})$ to prepare $2 \mathrm{M}$ $\mathrm{NaOH}$ solution.

\section{Synthesis of quercetin derivatives (2-15)}

\section{Synthesis of quercetin-3,3', $\mathbf{4}^{\prime}, 5,7$-pentaacetate (2)}

A mixture of quercetin $(\mathbf{1}, 302 \mathrm{mg}, 1 \mathrm{mmol})$, acetic anhydride $(9.4 \mathrm{ml})$ and pyridine $(3.8 \mathrm{ml})$ was stirred at $\mathrm{rt}$ for $5 \mathrm{~h}$ and then allowed to stand overnight ${ }^{13}$. On next day, distilled water $(30 \mathrm{ml})$ was added. A white solid product was collected and purified by recrystallization with ethanol to afford needles of compound $2(154 \mathrm{mg}, 30.1 \%)$. M. p. $=190^{\circ} \mathrm{C}$ (reported $\left.190^{\circ} \mathrm{C}\right)^{14} . \mathrm{R}_{\mathrm{f}}=0.85$ (hexane/ethyl acetate, 1:3). UV-Vis $\lambda_{\max } \mathrm{nm}: 308,258(\mathrm{MeOH}) ; 355,262(\mathrm{MeOH}+\mathrm{NaOAc}) ; 306,258\left(\mathrm{MeOH}+\mathrm{NaOAc}+\mathrm{H}_{3} \mathrm{BO}_{3}\right)$; 306, $253\left(\mathrm{MeOH}+\mathrm{AlCl}_{3}\right) ; 307,252\left(\mathrm{MeOH}+\mathrm{AlCl}_{3}+\mathrm{HCl}\right)$; and 394, $259(\mathrm{MeOH}+\mathrm{NaOH})$.

\section{Synthesis of quercetin-3,3',4',5-tetraacetate (3)}

A solution of imidazole $(25 \mathrm{mg}, 0.39 \mathrm{mmol})$ in $\mathrm{CH}_{2} \mathrm{Cl}_{2}(2.5 \mathrm{ml})$ was added drop wise to a solution of quercetin-3,3', $4^{\prime}, 5,7$-pentaacetate $(2,100 \mathrm{mg}, 0.2 \mathrm{mmol})$ in $\mathrm{CH}_{2} \mathrm{Cl}_{2}(5 \mathrm{ml})$ at $-15^{\circ} \mathrm{C}^{13}$. The resulting solution was warmed to rt and stirring was continued for $2 \mathrm{~h}$. The mixture was diluted with $\mathrm{CH}_{2} \mathrm{Cl}_{2}(25$ $\mathrm{ml})$ and washed with $3 \mathrm{M} \mathrm{HCl}(25 \mathrm{ml} \times 3)$. The organic layer was collected, dried over $\mathrm{Na}_{2} \mathrm{SO}_{4}$, filtered and concentrated. The residue was purified by silica gel column chromatography using $\mathrm{CHCl}_{3} /$ methanol (97:3) to afford compound 3 (47 mg, 50.0\%). $\mathrm{R}_{\mathrm{f}}=0.85$ (methanol/chloroform, 1:9). UV-Vis $\lambda_{\max } \mathrm{nm}$ : 309, $260(\mathrm{MeOH}) ; 354,266(\mathrm{MeOH}+\mathrm{NaOAc}) ; 308,258\left(\mathrm{MeOH}+\mathrm{NaOAc}+\mathrm{H}_{3} \mathrm{BO}_{3}\right) ; 307,254(\mathrm{MeOH}$ $\left.+\mathrm{AlCl}_{3}\right) ; 308,253\left(\mathrm{MeOH}+\mathrm{AlCl}_{3}+\mathrm{HCl}\right) ;$ and 394, $259(\mathrm{MeOH}+\mathrm{NaOH})$.

\section{Synthesis of quercetin $3,3^{\prime}, 4^{\prime}, 7$-tetraacetate (4)}

Acetic anhydride $(0.5 \mathrm{ml})$ was added drop wise to a solution of quercetin $(1,338 \mathrm{mg}, 1.2 \mathrm{mmol})$, pyridine $(1.7 \mathrm{ml})$ and $\mathrm{CH}_{2} \mathrm{Cl}_{2}(7 \mathrm{ml})^{13}$. After stirring at $\mathrm{rt}$ for $3 \mathrm{~h}$, the mixture was diluted with $\mathrm{CH}_{2} \mathrm{Cl}_{2}(40$ $\mathrm{ml})$. It was washed with $3 \mathrm{M} \mathrm{HCl}(30 \mathrm{ml} \times 3)$ and brine, dried over $\mathrm{MgSO}_{4}$ and then filtered through Celite ${ }^{\circledR}$. The residue obtained after solvent evaporation was purified by silica gel column 
chromatography using $\mathrm{CH}_{2} \mathrm{Cl}_{2}$ /hexane/ethyl acetate (9:2:1) to afford compound 4 (400 mg, 76.0\%). $\mathrm{R}_{\mathrm{f}}=$ $0.8\left(\mathrm{CH}_{2} \mathrm{Cl}_{2} /\right.$ hexane/ethyl acetate, 9:2:1). UV-Vis $\lambda_{\max } \mathrm{nm}: 349,264(\mathrm{MeOH}) ; 358,268(\mathrm{MeOH}+$ $\mathrm{NaOAc}) ; 373,262\left(\mathrm{MeOH}+\mathrm{NaOAc}+\mathrm{H}_{3} \mathrm{BO}_{3}\right) ; 429,274\left(\mathrm{MeOH}+\mathrm{AlCl}_{3}\right) ; 394,269\left(\mathrm{MeOH}+\mathrm{AlCl}_{3}+\right.$ $\mathrm{HCl})$; and 403, $271(\mathrm{MeOH}+\mathrm{NaOH})$.

\section{Synthesis of quercetin-3,4', 7-tribenzyl ether (5) and quercetin-3,3', $\mathbf{4}^{\prime}, 7$-tetrabenzyl ether (6)}

Benzyl bromide $(2.2 \mathrm{ml}, 18 \mathrm{mmol})$ was added to the mixture of quercetin $(1,906 \mathrm{mg}, 3 \mathrm{mmol})$ and $\mathrm{K}_{2} \mathrm{CO}_{3}(1.4 \mathrm{~g}, 10 \mathrm{mmol})$ in DMF $(20 \mathrm{ml})^{15}$. After overnight stirring at $\mathrm{rt}$, the mixture was diluted with $0.3 \mathrm{M} \mathrm{HCl}(60 \mathrm{ml})$ and then extracted with EtOAc $(35 \mathrm{ml} \times 3)$. The combined organic layer was washed with brine, dried over $\mathrm{Na}_{2} \mathrm{SO}_{4}$, filtered and concentrated. The resulting residue was purified by column chromatography using $\mathrm{CHCl}_{3} / \mathrm{EtOAc}(97.5: 2.5)$ to afford compounds 5 (162 mg, 9.4\%) and 6 (85 mg, $4.3 \%)$.

Quercetin-3,4',7-tribenzyl ether (5). $\mathrm{R}_{\mathrm{f}}=0.7\left(\mathrm{CH}_{2} \mathrm{Cl}_{2}\right)$. M. p. $=150^{\circ} \mathrm{C}\left(\text { reported } 150-152^{\circ} \mathrm{C}\right)^{15}$. UVVis $\lambda_{\max } \mathrm{nm}: 352,257(\mathrm{MeOH}) ; 353,257(\mathrm{MeOH}+\mathrm{NaOAc}) ; 352,257\left(\mathrm{MeOH}+\mathrm{NaOAc}+\mathrm{H}_{3} \mathrm{BO}_{3}\right) ; 399$, $272\left(\mathrm{MeOH}+\mathrm{AlCl}_{3}\right) ; 401,272\left(\mathrm{MeOH}+\mathrm{AlCl}_{3}+\mathrm{HCl}\right) ;$ and 375, $283(\mathrm{MeOH}+\mathrm{NaOH})$.

Quercetin-3,3',4',7-tetrabenzyl ether (6). $\mathrm{R}_{\mathrm{f}}=0.8\left(\mathrm{CH}_{2} \mathrm{Cl}_{2}\right)$. M. p. $=140^{\circ} \mathrm{C}\left(\text { reported } 140-142^{\circ} \mathrm{C}\right)^{15}$. UV-Vis $\lambda_{\max } \mathrm{nm}: 354,256(\mathrm{MeOH}) ; 353,257(\mathrm{MeOH}+\mathrm{NaOAc}) ; 354,257\left(\mathrm{MeOH}+\mathrm{NaOAc}+\mathrm{H}_{3} \mathrm{BO}_{3}\right)$; 402, $274\left(\mathrm{MeOH}+\mathrm{AlCl}_{3}\right) ; 401,274\left(\mathrm{MeOH}+\mathrm{AlCl}_{3}+\mathrm{HCl}\right) ;$ and 377, $272(\mathrm{MeOH}+\mathrm{NaOH})$.

\section{Synthesis of quercetin-3,4',7-tribenzyl-3'-methyl ether (7) and quercetin-3,3',4',7-tetrabenzyl-5- methyl ether (8)}

Benzyl bromide (2.2 ml, $18 \mathrm{mmol})$ was added to the mixture of quercetin $(1,906 \mathrm{mg}, 3 \mathrm{mmol})$ and $\mathrm{K}_{2} \mathrm{CO}_{3}(1.4 \mathrm{~g}, 10 \mathrm{mmol})$ in DMF $(20 \mathrm{ml})^{15}$. After overnight stirring at $\mathrm{rt}$, to this was added $\mathrm{K}_{2} \mathrm{CO}_{3}(420$ $\mathrm{mg}, 3 \mathrm{mmol})$ and excess of MeI $(0.74 \mathrm{ml}, 12 \mathrm{mmol})$. Stirring was continued for 1 day and then quenched with $0.3 \mathrm{M} \mathrm{HCl}(60 \mathrm{ml})$. The reaction mixture was extracted with EtOAc $(35 \mathrm{ml} \times 3)$. The combined organic layer was washed with brine, dried over $\mathrm{Na}_{2} \mathrm{SO}_{4}$, filtered and concentrated. The resulting residue was purified by repeated silica gel column chromatography using $\mathrm{CHCl}_{3} / \mathrm{EtOAc}$ (19:1) and hexane/EtOAc (8:2) as eluents. Further purification was achieved with MPLC using hexane/EtOAc (8:2) to afford compounds 7 (76 mg, 4.3\%) and $\mathbf{8}(76 \mathrm{mg}, 3.7 \%)$.

Quercetin-3,4',7-tribenzyl-3'-methyl ether (7). $\mathrm{R}_{\mathrm{f}}=0.47$ (EtOAC/hexane, 2:8). M. p. $=142^{\circ} \mathrm{C}$ (reported $\left.142-144^{\circ} \mathrm{C}\right)^{15}$. UV-Vis $\lambda_{\max } \mathrm{nm}: 352,256(\mathrm{MeOH}) ; 351,256(\mathrm{MeOH}+\mathrm{NaOAc}) ; 352,256$ $\left(\mathrm{MeOH}+\mathrm{NaOAc}+\mathrm{H}_{3} \mathrm{BO}_{3}\right) ; 401,273\left(\mathrm{MeOH}+\mathrm{AlCl}_{3}\right) ; 401,275\left(\mathrm{MeOH}+\mathrm{AlCl}_{3}+\mathrm{HCl}\right) ;$ and 374, 283 $(\mathrm{MeOH}+\mathrm{NaOH})$.

Quercetin-3,3',4',7-tetrabenzyl-5-methyl ether (8). $\mathrm{R}_{\mathrm{f}}=0.66$ (EtOAC/hexane, 2:8). M. p. $=153^{\circ} \mathrm{C}$ (reported 156-158 $\left.{ }^{\circ} \mathrm{C}\right)^{15}$. UV-Vis $\lambda_{\max } \mathrm{nm}: 334,258(\mathrm{MeOH}) ; 353,259(\mathrm{MeOH}+\mathrm{NaOAc}) ; 354,258$ $\left(\mathrm{MeOH}+\mathrm{NaOAc}+\mathrm{H}_{3} \mathrm{BO}_{3}\right) ; 366,272\left(\mathrm{MeOH}+\mathrm{AlCl}_{3}\right) ; 359,272\left(\mathrm{MeOH}+\mathrm{AlCl}_{3}+\mathrm{HCl}\right) ;$ and 377, 272 $(\mathrm{MeOH}+\mathrm{NaOH})$. 


\section{J. Nepal Chem. Soc., Vol.37, 2017}

\section{Synthesis of quercetin-3,4',7-tribenzyl-3',5-dimethyl ether (9)}

Iodomethane $(0.10 \mathrm{ml}, 1.6 \mathrm{mmol})$ was treated with quercetin-3,4',7-tribenzyl ether $(\mathbf{5}, 200 \mathrm{mg}, 0.35$ $\mathrm{mmol})$ and $\mathrm{K}_{2} \mathrm{CO}_{3}(150 \mathrm{mg}, 1 \mathrm{mmol})$ in DMF $(5 \mathrm{ml})^{15}$. After overnight stirring at rt, the reaction mixture was diluted with $0.3 \mathrm{M} \mathrm{HCl}(10 \mathrm{ml})$. It was extracted with EtOAc $(30 \mathrm{ml} \times 2)$. The combined organic layer was washed with brine, dried over $\mathrm{Na}_{2} \mathrm{SO}_{4}$, filtered and concentrated. The crude product was purified by column chromatography using $\mathrm{CH}_{2} \mathrm{Cl}_{2}$ to afford compound 9 ( $82 \mathrm{mg}, 39.4 \%$ ). $\mathrm{R}_{\mathrm{f}}=0.8$ $\left(\mathrm{CH}_{2} \mathrm{Cl}_{2}\right)$. M. p. $=140^{\circ} \mathrm{C}$ (reported $\left.139.6^{\circ} \mathrm{C}\right)^{16}$. UV-Vis $\lambda_{\max } \mathrm{nm}: 353,255(\mathrm{MeOH}) ; 352,255(\mathrm{MeOH}+$ $\mathrm{NaOAc}) ; 353,255\left(\mathrm{MeOH}+\mathrm{NaOAc}+\mathrm{H}_{3} \mathrm{BO}_{3}\right) ; 363,272\left(\mathrm{MeOH}+\mathrm{AlCl}_{3}\right) ; 356,273\left(\mathrm{MeOH}+\mathrm{AlCl}_{3}+\right.$ $\mathrm{HCl})$; and 372, $283(\mathrm{MeOH}+\mathrm{NaOH})$.

\section{Synthesis of quercetin-3'-methyl ether (10)}

A suspension of quercetin-3,4',7-tribenzyl-3'-methyl ether (7, $50 \mathrm{mg}, 0.085 \mathrm{mmol}), \mathrm{HCl}(5 \mathrm{ml}, 36 \%)$ and glacial acetic acid $(5 \mathrm{ml})$ was refluxed for $4 \mathrm{~h}$ and then cooled down to $\mathrm{rt}^{16}$. The reaction mixture was diluted with water $(30 \mathrm{ml})$ and extracted with EtOAc $(30 \mathrm{ml} \times 3)$. The combined organic layer was washed with saturated $\mathrm{NaHCO}_{3}$ and brine. Then it was dried over $\mathrm{Na}_{2} \mathrm{SO}_{4}$, filtered and concentrated. The resulting residue was purified by silica gel column chromatography using hexane/EtOAc (1:1) to afford compound $10(18 \mathrm{mg}, 66.7 \%)$. $\mathrm{R}_{\mathrm{f}}=0.7$ (EtOAc/hexane, 3:1). UV-Vis $\lambda_{\max } \mathrm{nm}: 370,257(\mathrm{MeOH}) ; 374$, $257(\mathrm{MeOH}+\mathrm{NaOAc}) ; 384,260\left(\mathrm{MeOH}+\mathrm{NaOAc}+\mathrm{H}_{3} \mathrm{BO}_{3}\right) ; 445,270\left(\mathrm{MeOH}+\mathrm{AlCl}_{3}\right) ; 428,267$ $\left(\mathrm{MeOH}+\mathrm{AlCl}_{3}+\mathrm{HCl}\right) ;$ and 417, $327(\mathrm{MeOH}+\mathrm{NaOH})$.

\section{Synthesis of quercetin-5-methyl ether (11)}

A suspension of quercetin-3,3',4',7-tetrabenzyl-5-methyl ether $(\mathbf{8}, 50 \mathrm{mg}, 0.073 \mathrm{mmol}), \mathrm{HCl}(5 \mathrm{ml}$, $36 \%)$ and glacial acetic acid $(5 \mathrm{ml})$ was refluxed for $4 \mathrm{~h}$ and then cooled down to $\mathrm{rt}^{16}$. The reaction mixture was diluted with water $(30 \mathrm{ml})$ and extracted with EtOAc $(30 \mathrm{ml} \times 3)$. The combined organic layer was washed with saturated $\mathrm{NaHCO}_{3}$ and brine. Then it was dried over $\mathrm{Na}_{2} \mathrm{SO}_{4}$, filtered and concentrated. The resulting residue was purified by silica gel column chromatography using hexane/EtOAc (3:1) to afford compound 11 (21.3 mg, 92.2\%). $\mathrm{R}_{\mathrm{f}}=0.7$ (EtOAc/hexane, 3:1). UV-Vis $\lambda_{\max }$ nm: 372, $256(\mathrm{MeOH}) ; 373,256(\mathrm{MeOH}+\mathrm{NaOAc}) ; 385,260\left(\mathrm{MeOH}+\mathrm{NaOAc}+\mathrm{H}_{3} \mathrm{BO}_{3}\right) ; 447,270$ $\left(\mathrm{MeOH}+\mathrm{AlCl}_{3}\right) ; 430,267\left(\mathrm{MeOH}+\mathrm{AlCl}_{3}+\mathrm{HCl}\right) ;$ and 408, $330(\mathrm{MeOH}+\mathrm{NaOH})$.

\section{Synthesis of quercetin-3',5-dimethyl ether (12)}

A suspension of quercetin-3,4',7-tribenzyl-3',5-dimethyl ether (9, $50 \mathrm{mg}, 0.083 \mathrm{mmol}), \mathrm{HCl}(5 \mathrm{ml}$, $36 \%)$ and glacial acetic acid $(5 \mathrm{ml})$ was refluxed for $4 \mathrm{~h}$ and then cooled down to $\mathrm{rt}^{16}$. The reaction mixture was diluted with water $(30 \mathrm{ml})$ and extracted with EtOAc $(30 \mathrm{ml} \times 3)$. The combined organic layer was washed with saturated $\mathrm{NaHCO}_{3}$ and brine. Then it was dried over $\mathrm{Na}_{2} \mathrm{SO}_{4}$, filtered and concentrated. The resulting residue was purified by silica gel column chromatography using hexane/EtOAc (9:1) to afford compound $12(15.3 \mathrm{mg}, 55.6 \%) . \mathrm{R}_{\mathrm{f}}=0.6\left(\mathrm{EtOAc} / \mathrm{CH}_{2} \mathrm{Cl}_{2}, 1: 3\right)$. UV-Vis $\lambda_{\max } \mathrm{nm}: 371,254(\mathrm{MeOH}) ; 374,270(\mathrm{MeOH}+\mathrm{NaOAc}) ; 370,255\left(\mathrm{MeOH}+\mathrm{NaOAc}+\mathrm{H}_{3} \mathrm{BO}_{3}\right) ; 429,264$ $\left(\mathrm{MeOH}+\mathrm{AlCl}_{3}\right) ; 429,263\left(\mathrm{MeOH}+\mathrm{AlCl}_{3}+\mathrm{HCl}\right) ;$ and 423, $276(\mathrm{MeOH}+\mathrm{NaOH})$.

\section{Synthesis of quercetin-3,4',7-trimethyl ether (13) and quercetin-3,3',4',7-tetramethyl ether (14)}

A mixture of quercetin $(1,302 \mathrm{mg}, 1 \mathrm{mmol}), \mathrm{K}_{2} \mathrm{CO}_{3}(415 \mathrm{mg}, 3 \mathrm{mmol})$ and DMF $(8 \mathrm{ml})$ was stirred at rt for $30 \mathrm{~min}^{16}$. To this was added $\mathrm{MeI}(0.3 \mathrm{ml}, 4.3 \mathrm{mmol})$ and stirring was continued for overnight. The 
mixture was diluted with $0.2 \mathrm{M} \mathrm{HCl}(20 \mathrm{ml})$ and then extracted with ethyl acetate $(30 \mathrm{ml} \times 3)$. The combined organic layer was washed with brine, dried over $\mathrm{Na}_{2} \mathrm{SO}_{4}$, filtered and concentrated. The resulting residue was purified by silica gel column chromatography using $\mathrm{CHCl}_{3} / \mathrm{EtOAc}$ (95:5) to obtain compounds $\mathbf{1 3}$ (190 mg, 55.0\%) and $\mathbf{1 4}$ (91 mg, 25.4\%).

Quercetin-3,4',7-trimethyl ether (13). $\mathrm{R}_{\mathrm{f}}=0.4\left(\mathrm{CHCl}_{3} /\right.$ EtOAc, 19:1). UV-Vis $\lambda_{\max } \mathrm{nm}$ : 353, 256 $(\mathrm{MeOH}) ; 354,255(\mathrm{MeOH}+\mathrm{NaOAc}) ; 353,256\left(\mathrm{MeOH}+\mathrm{NaOAc}+\mathrm{H}_{3} \mathrm{BO}_{3}\right) ; 394,267\left(\mathrm{MeOH}+\mathrm{AlCl}_{3}\right)$; 399, $267\left(\mathrm{MeOH}+\mathrm{AlCl}_{3}+\mathrm{HCl}\right)$; and 378, $270(\mathrm{MeOH}+\mathrm{NaOH})$.

Quercetin-3,3',4',7-tetramethyl ether (14). $\mathrm{R}_{\mathrm{f}}=0.7\left(\mathrm{CHCl}_{3} / \mathrm{EtOAc}, 19: 1\right) . \mathrm{M} . \mathrm{p} .=155-156^{\circ} \mathrm{C}$ (reported 156-161 $\left.{ }^{\circ} \mathrm{C}\right)^{17}$. UV-Vis $\lambda_{\max } \mathrm{nm}: 351,254(\mathrm{MeOH}) ; 352,254(\mathrm{MeOH}+\mathrm{NaOAc}) ; 351,254$ $\left(\mathrm{MeOH}+\mathrm{NaOAc}+\mathrm{H}_{3} \mathrm{BO}_{3}\right) ; 399,267\left(\mathrm{MeOH}+\mathrm{AlCl}_{3}\right) ; 398,267\left(\mathrm{MeOH}+\mathrm{AlCl}_{3}+\mathrm{HCl}\right) ;$ and 374, 283 $(\mathrm{MeOH}+\mathrm{NaOH})$.

\section{Synthesis of quercetin-3,3', $\mathbf{4}^{\prime}, 5,7$-pentamethyl ether (15)}

A mixture of quercetin $(1,302 \mathrm{mg}, 1 \mathrm{mmol}), \mathrm{K}_{2} \mathrm{CO}_{3}(829 \mathrm{mg}, 6 \mathrm{mmol})$ and DMF $(10 \mathrm{ml})$ was stirred at $\mathrm{rt}$ for $30 \mathrm{~min}^{16}$. To this was added MeI $(0.7 \mathrm{ml}, 11 \mathrm{mmol})$ and stirring was continued for overnight. The mixture was diluted with $0.2 \mathrm{M} \mathrm{HCl}(25 \mathrm{ml})$ and then extracted with ethyl acetate $(50 \mathrm{ml} \times 3)$. The combined organic layer was washed with brine, dried over $\mathrm{Na}_{2} \mathrm{SO}_{4}$, filtered and concentrated. The resulting residue was recrystallized from EtOAc affording pale yellow crystals of compound $\mathbf{1 5}$ (223 mg, 59.8\%). M. p. $=152^{\circ} \mathrm{C}\left(\text { reported } 152-156^{\circ} \mathrm{C}\right)^{16} . \mathrm{R}_{\mathrm{f}}=0.5\left(\mathrm{CHCl}_{3} / \mathrm{EtOAc}, 1: 1\right)$. UV-Vis $\lambda_{\max } \mathrm{nm}: 340,249$ $(\mathrm{MeOH}) ; 341,249(\mathrm{MeOH}+\mathrm{NaOAc}) ; 342,249\left(\mathrm{MeOH}+\mathrm{NaOAc}+\mathrm{H}_{3} \mathrm{BO}_{3}\right) ; 340,250\left(\mathrm{MeOH}+\mathrm{AlCl}_{3}\right)$; $341,249\left(\mathrm{MeOH}+\mathrm{AlCl}_{3}+\mathrm{HCl}\right)$; and 342, $250(\mathrm{MeOH}+\mathrm{NaOH})$.

\section{Results and Discussion}

Quercetin (1) is a lead compound in designing of antioxidants since this polyphenol exhibited a high antioxidant capacity ${ }^{18,19}$. In continuation of search of molecules with enhanced antioxidant capacity in our undergoing research, fourteen quercetin derivatives (2-15) were synthesized following reported procedures (Scheme 1). Upon acetylation of commercially available quercetin (1) in the presence of pyridine, quercetin 3,3',4',5,7-pentaacetate (2) was obtained by the use of excess amounts of acetic anhydride, while quercetin $3,3^{\prime}, 4^{\prime}, 7$-tetraacetate (4) was formed regioselectively by adding comparably less amount of acetylating agent in $\mathrm{CH}_{2} \mathrm{Cl}_{2}$. Treatment of compound 2 with imidazole selectively removed acetyl functionality at 7-position affording quercetin 3,3',4',5-tetraacetate (3). Regioselective methylation of quercetin (1) was achieved when the amount of methylating agent was varied. When an excess amount of MeI was used, quercetin 3,3',4',5,7-pentamethyl ether (15) was obtained and when a less amount of MeI was used, the reaction yielded quercetin 3,4',7-trimethyl ether (13) and quercetin 3,3',4',7-tetramethyl ether (14). Quercetin 3,4',7-tribenzyl ether (5) and quercetin 3,3',4',7-tetrabenzyl ether (6) were synthesized by using $\mathrm{BnBr}$ as an alkylating agent. Regioselective methylation of compound 5 using MeI led to synthesis of quercetin 3,4',7-tribenzyl-3'-methyl ether (7), quercetin 3,4',7-tribenzyl3',5-dimethyl ether (9) and quercetin 3,3',4',7-tetrabenzyl-5-methyl ether (8). Hydrolysis of compounds $\mathbf{5 ,} 8$ and 9 yielded corresponding debenzylated products quercetin 3'-methyl ether (10), quercetin 5methyl ether (11) and quercetin 3',5-dimethyl ether (12), respectively. 


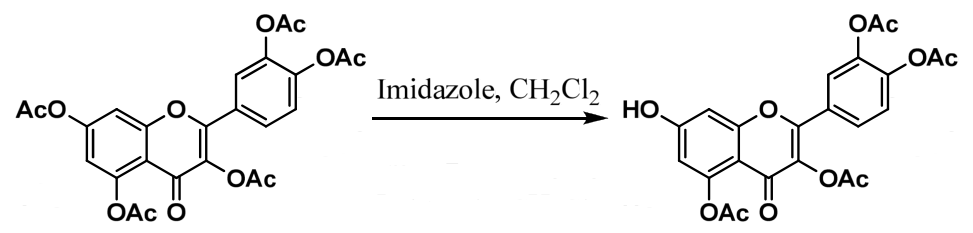

$(2,30.1 \%)$

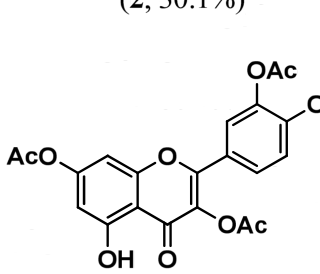

(4, 76.0\%)<smiles>COc1cc(OC)c2c(=O)c(OC)c(-c3ccc(OC)c(OC)c3)oc2c1</smiles>

$(15,59.8 \%)$

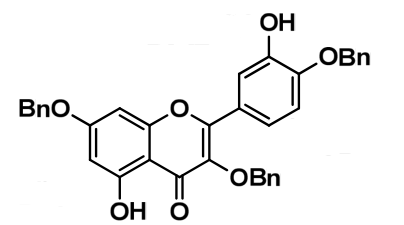

$(5,9.4 \%)$<smiles>CC(C)(C)[N+](C)(C)C</smiles>

$(7,4.3 \%)$

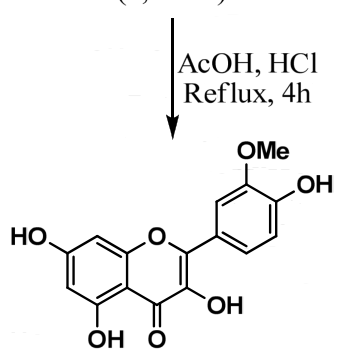

$(10,66.7 \%)$

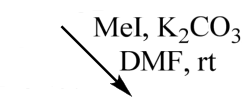

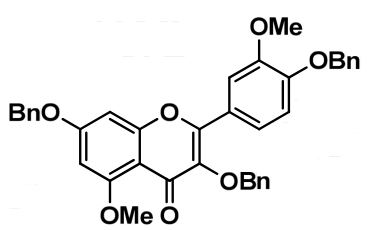

(9, 39.4\%)<smiles>COc1cc(O)cc2oc(-c3ccc(O)c(O)c3)c(O)c(=O)c12</smiles>

(12, 55.6\%)<smiles>COc1cc(O)c2c(=O)c(OC)c(-c3ccc(OC)c(OC)c3)oc2c1</smiles>

(14, 25.4\%)<smiles>COc1cc(O)c2c(=O)c(OC)c(-c3ccc(OC)c(O)c3)oc2c1</smiles>

(13, 55.0\%)<smiles></smiles>

$(6,4.3 \%)$

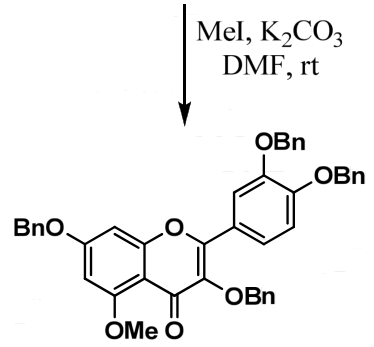

$(8,3.7 \%)$<smiles>OC1=C(c2ccc(O)c(O)c2)c2cc(O)cc(O)c2Oc2cc(O)cc(O)c21</smiles>

(11, 92.2\%)

Scheme 1: Synthesis of quercetin derivatives (2-15). 
The UV-Vis spectrum of commercial quercetin (1) in methanol showed two absorption maxima at 372 $\mathrm{nm}$ (band I) and $257 \mathrm{~nm}$ (band II). A bathochromic shift of $17 \mathrm{~nm}$ in band II upon addition of NaOAc indicated the presence of a free 7-OH. A $+14 \mathrm{~nm}$ shift of band I compared to the methanolic spectrum with further addition of $\mathrm{H}_{3} \mathrm{BO}_{3}$ was due to the presence of 3', ','-diOH. Addition of $\mathrm{AlCl}_{3}$ to a methanolic solution of compound $\mathbf{1}$ produced an immediate intense yellow color and is reflected as $78 \mathrm{~nm}$ bathochromic shift in band I due to the chelation between the carbonyl group and the adjacent 5-OH and/or 3-OH group(s). While in the presence of $\mathrm{AlCl}_{3}$ along with $\mathrm{HCl}$, it showed $+57 \mathrm{~nm}$ shift in band I because of a free 5-OH group. When $\mathrm{NaOH}$ was used as a shift reagent, a bathochromic shift of $57 \mathrm{~nm}$ in band I relative to $\mathrm{MeOH}$ spectrum has supported the presence of 3,4'-diOH. All the spectra and analysis data are provided in Supplementary Material.

Despite some changes in spectral pattern were observed at a first sight, UV-Vis shift reagent spectral analysis of pentaacetate substituted compound $\mathbf{2}$ showed no remarkable changes in peak maxima except in the spectrum with $\mathrm{NaOH}$. In the later spectrum, $86 \mathrm{~nm}$ of bathochromic shift in band I was observed (relative to $\mathrm{MeOH}$ spectrum). Bathochromic shift of 50-60 nm is indicative for free 3-OH or 3,4'- $\mathrm{diOH}^{8}$, but when these positions are substituted, the shift range would be varied. For examples, compounds 2 and 3 showed about $+85 \mathrm{~nm}$ shift, compounds 5, 6, 7, 8, 9, 13 and 14 showed about $+23 \mathrm{~nm}$ shift, and compound 15 apparently showed no shift in band $\mathrm{I}$ in the $\mathrm{NaOH}$ spectrum. Furthermore, 47 and $36 \mathrm{~nm}$ bathochromic shifts in band I were appeared in the cases of compounds $\mathbf{1 0}$ and 11, which contained free 3,4'-diOH. Therefore, the range 50-60 $\mathrm{nm}$ bathochromic shift in band I in $\mathrm{NaOH}$ spectrum due to free 3,4 '-diOH given in general consideration should be revised with a new range of 35-60 nm. Supporting to the general rule, a shoulder and/or prominent peak at $330 \mathrm{~nm}$ was appeared on addition of $\mathrm{NaOH}$ when compounds 3, 10, 11 and 12 bearing a free 7-OH group were used.

Flavonol containing a free 3-OH group chelates with $\mathrm{AlCl}_{3}$, which causes a bathochromic shift in band I. Flavonoid containing a free 5-OH group also produces similar effect. We observed that a free 3$\mathrm{OH}$ produces a bathochromic shift of 58-78 nm (as in compounds 10, 11 and 12) and a free 5-OH group shifts the band in a lesser extent of 41-49 nm (as in compounds 5, 6, 7, 13 and 14) when $\mathrm{AlCl}_{3}$ was introduced. As an exception, compound 4, which contained a free 5-OH produced $+80 \mathrm{~nm}$ shift. This feature may be employed to distinguish between a free $3-\mathrm{OH}$ and $5-\mathrm{OH}$ group in flavonoids.

As described above, a free 3-OH and/or 5-OH along with $\mathrm{C} 4$ keto group chelates with $\mathrm{AlCl}_{3}$ and thus complex formed is stable in the acidic condition. In the case of compound 11 possessing both 3', 4'-diOH and 3-OH groups produced $75 \mathrm{~nm}$ of bathochromic shift with $\mathrm{AlCl}_{3}$ (relative to $\mathrm{MeOH}$ spectrum) and the shift became +58 (relative to $\mathrm{MeOH}$ spectrum) after addition of $\mathrm{HCl}$ indicating intact chelation of 3-OH to $\mathrm{AlCl}_{3}$. When compound 12 bearing a free 3-OH but not ortho-dihydroxyl groups was employed, a +58 shift was observed by using both $\mathrm{AlCl}_{3}$ and $\mathrm{AlCl}_{3}+\mathrm{HCl}$ shift reagents indicating involvement of 3-OH group in the chelation. Compounds $\mathbf{1}$ and $\mathbf{1 0}$ bearing both free 3-OH and 5-OH groups produced 78 and $75 \mathrm{~nm}$ bathochromic shifts in band I after addition of $\mathrm{AlCl}_{3}$, and 57 and $58 \mathrm{~nm}$ bathochromic shifts after further addition of $\mathrm{HCl}$, respectively. These results indicated that a free 3-OH group preferably chelates with $\mathrm{AlCl}_{3}$ in comparison to an available free 5-OH group.

\section{Conclusions}

The UV-Vis spectral analysis of quercetin (1) and its derivatives (2-15) using various shift reagents led us to draw following new insights in the structure elucidation of flavonoids: (a) addition of $\mathrm{AlCl}_{3}$ 


\section{J. Nepal Chem. Soc., Vol.37, 2017}

produces a bathochromic shift of 58-78 $\mathrm{nm}$ in band I due to a free 3-OH group, while a free 5-OH group produces 41-49 $\mathrm{nm}$ bathochromic shift, and (b) a free 3,4'-diOH can produce 35-60 nm bathochromic shift in band $\mathrm{I}$ in the presence of $\mathrm{NaOH}$ as a shift reagent and the range varies when the positions are substituted. In the present study, 6-O and 8-O-substituted flavonols were not considered, which perhaps may not be produced significant effects.

\section{Acknowledgements}

The World Academy of Sciences (TWAS) is gratefully acknowledged for supporting our research program by providing prestigious instruments. Thanks to Dr. Deependra Das Mulmi, Senior Scientific Officer at Nepal Academy of Science and Technology (NAST) for helping us in recording of UV-Vis spectra.

\section{References}

1. E. Grotewold (editor), The science of flavonoids, Springer Science, Business Media, Inc., New York, USA, 2006.

2. Ø.M. Andersen and K.R. Markham (editors), Flavonoids: chemistry, biochemistry and applications, Taylor and Francis, Boca Raton, London, New York, 2006.

3. J.B. Harborne and C.A. Williams, Phytochemistry, 2000, 55, 481-504.

4. T.J. Mabry, K.R. Markham and M.B. Thomas, The systematic identification of flavonoids, Springer-Verlag, Berlin, Heidelberg, New York, 1970.

5. T.J. Mabry, K.R. Markham and M.B. Thomas, The systematic identification of flavonoids, Springer-Verlag, Berlin, Heidelberg, New York, 1970, 41-164.

6. K.-H.A., Rosler and D.P.C. Wong, J. Nat. Prod., 1985, 48, 837-840.

7. V.H. Dietz, E. Wollenweber, J. Favre-Bonvin and L.D. Gomez, Z. Naturforsch., 1980, 35C, 36-40.

8. E. Wollenweber, In The Flavonoids, J.B. Harborne and T.J. Mabry, editors, Springer Science, Business Media Dordrecht, 1982, 189-260.

9. E. Wollenweber and M. Jay, In The flavonoids: advances in research since 1980, J.B. Harborne, editor, Springer Science, Business Media Dordrecht, 1988, 233-302.

10. K.R. Markham and T.J. Mabry, In The flavonoids, J.B. Harborne, T.J. Mabry and H. Mabry, editor, Springer Science and Business Media Dordrecht, Chapman and Hall Ltd., 1975, 45-77.

11. K.R. Markham, Techniques of flavonoids identification, Academic Press, London, 1982.

12. J.B. Harborne, Comparative biochemistry of the flavonoids, Academic Press, New York, 1967.

13. A. Mattarei, L. Biasutto, F. Rastrelli, S. Garbisa, E. Marotta, M. Zoratti and C. Paradisi, Molecules, 2010, 15, 4722-4736.

14. S. Clevenger, Archives Biochem. Biophy., 1958, 76, 131-138.

15. M. Bouktaib, S. Lebrun, A. Atmani and C. Rolando, Tetrahedron, 2002, 58, 10001-10009.

16. M. Moalin, G.P.F. van Strijdonck, M. Beckers, G.J. Hagemen, P.J. Borm, A. Bast and G.R. Haenen, Molecules, 2011, 16, 9636-9650.

17. Z. Sroka, Zeitschrift für Naturforschung C, 2005, 60, 833-843.

18. M. Materska, Pol. J. Food Nutr. Sci., 2008, 58, 407-413.

19. A. Arora, M.G. Nair and G.M. Strasburg, Free Rad. Bio. Med., 1998, 24, 1355-1363. 